\title{
PEMBERDAYAAN MASYARAKAT PRASEJAHTERA MELALUI INOVASI KERIPIK PISANG RUMPUT LAUT DI DESA PAJATEN KECAMATAN SIDAMULIH
}

\author{
Regi Refian Garis*, R. Rindu Garvera, Purnama Sari \\ FISIP Universitas Galuh \\ *Email: regirefiangaris@yahoo.com
}

\begin{abstract}
ABSTRAK
Tujuan diadakannya kegiatan pengabdian kepada masyarakat ini adalah untuk memberikan pelatihan kreativitas masyarakat berupa inovasi produk makanan dan menciptakan peluang usaha bagi masyarakat desa. Metode yang digunakan antara lain metode ceramah untuk memberikan pengetahuan sedangkan metode demonstrasi digunakan untuk memberikan pelatihan kreativitas pembuatan produk sebagai prduk unggulan. Kegiatan ini dilaksanakan selama 2 (dua) bulan, dimana terdapat beberapa tahapan kegiatan, antara lain: (1) observasi awal; (2) pengagendaan kegiatan; (3) pelaksanaan kegiatan; (4) pendampingan manajemen usaha; (5) evaluasi akhir, dan; (6) pemantauan khusus yang keberlanjutan. Hasil dari pengabdian ini antara lain: 1) terbentuknya kelompok yang sadar akan pentingnya berwirausaha, 2) terbentuknya inovasi baru di sektor kuliner berupa keripik pisang rumput laut, dan 3) terciptanya produk unggulan desa.
\end{abstract}

Kata kunci: inovasi, pemberdayaan masyarakat, masyarakat prasejahtera

\section{PENDAHULUAN}

Realitas mengenai kemiskinan dan kesenjangan sosial masih menjadi permasalahan sosial yang dihadapi Indonesia sampai saat ini. Ketidakmerataan pembangunan ekonomi menjadi salah satu penyebab terjadinya kemiskinan. Oleh karena itu, pengentasan kemiskinan dan pemerataan pembangunan menjadi aspek yang penting dalam agenda kebijakan pemerintah. Pembangunan desa di Indonesia merupakan bagian integral dari pembangunan nasional yang dititik beratkan pada pembangunan ekonomi dengan peningkatan tarap hidup masyarakat. Dalam usaha meningkatkan taraf dan kualitas hidup masyarakat di pedesaan perlu digali cara-cara pengelolaan usaha yang paling sesuai. Salah satu potensi yang dapat dikembangkan adalah pembinaan kelompok-kelompok masyarakat melalui inovasi produk yang mudah dipahami oleh masyarakat sebagai media peningkatan kesejahteraan hidup mereka. Mubyarto dalam Yuniarti (2014) menyatakan bahwa kualitas manusia memang menjadi tujuan pembangunan dan kualitas tersebut yang di mengerti sebagai manusia yang mandiri dan bermanfaat, manusia yang lebih produktif, efisien dan bermoral.

Adapun langkah yang sangat penting dalam proses pelibatan masyarakat tersebut adalah dengan memberikan pelatihan kepada kelompok masyarakat untuk mengenal produk baru makanan sebagai keterampilan kewirausahaan. Di Indonesia, wirausaha sosial tumbuh dengan cepat seiring dengan keyakinan bahwa kewirausahaan sosial dapat mengatasi masalahmasalah sosial (Utomo, 2014). Ini terbukti dengan didirikannya Asosiasi Kewirausahaan Sosial Indonesia (AKSI) pada tahun 2009. 
Inovasi merupakan suatu proses dari hasil pengembangan suatu produk yang telah ada sebelumnya sehingga produk tersebut memiliki milai yang lebih berarti. Adapun manfaat inovasi adalah untuk menyempurnakan ataupun meningkatkan fungsi dari pemanfaatan suatu produk sehingga dapat bermanfaat lebih. Dan secara umum, tujuan inovasi adalah untuk meningkatkan kualitas dan juga nilai sesuatu hal yang sudah ada.

Mendefinisikan inovasi produk sebagai gabungan dari berbagai macam proses yang saling mempengaruhi antara satu dengan yang lain (Kotler, 2007). Inovasi produk merupakan produk atau jasa baru yang diperkenalkan ke pasar. Inovasi produk dikategorikan sebagai produk baru bagi dunia, lini produk baru, tambahan pada lini produk baru yang telah ada, perbaikan dan revisi produk yang telah ada, penentuan kembali dan pengurangan biaya (Nasution, 2005).

Masyarakat sasaran dalam pelatihan pembuatan inovasi produk makanan ini adalah masyarakat miskin/prasejahtera yang berada di Desa Pajaten. Dilihat dari aspek ekonomi, lebih dari 50 persen keluarga di Desa Pajaten berada pada kondisi prasejahtera. Prasejahtera sendiri merupakan keluarga-keluarga yang belum dapat memenuhi kebutuhan dasarnya secara minimal, seperti kebutuhan sandang, pangan, papan, kesehatan dan pendidikan. Hasil wawancara menunjukkan, rata-rata penghasilan warga yang berprofesi sebagai tukang dan serabutan di Desa Pajaten berada pada kisaran Rp 500.000 - Rp 700.000.

Pemberdayaan masyarakat perlu digalakan untuk meningkatkan ekonomi keluarga. Pembentukan kelompok masyarakat yang mandiri secara ekonomi dengan dibekali keterampilan dan keahlian serta inovasi-inovasi tambahan mengenai produk-produk makanan khas daerah lokal diharapkan bisa meningkatkan taraf dan kesejahteraan hidup masyarakat. Disinilah peran motivator luar yang berfungsi melakukan persiapan sosial menjadi penting. Persiapan sosial tidak lain adalah mengajak segenap anggota kelompok sasaran untuk mulai bersedia melakukan kegiatan mempersiapkan diri dengan mengidentifikasi kebutuhan dan mencari solusinya (Karsidi, 2005).

Hasil penelitian Marwanti (2011) menemukan bahwa rumusan model pemberdayaan masyarakat melalui pembelajaran pendidikan keaksaraan terintegrasi dengan life skills berbasis potensi daerah dapat meningkatkan antusiasme dan motivasi peserta didik karena mereka tidak hanya memperoleh kemampuan pedagogis melainkan juga kemampuan ekonomis. Dari hasil penelitian dengan pendekatan research and development yang dilakukan direkomendasikan agar pendidikan life skills berbasis potensi daerah perlu dikembangkan di seluruh wilayah Indonesia dengan memperhatikan perbedaan potensi lokal daerah dan life skills yang diminati peserta didik. Pemberian pelatihan life skills yang diberikan kepada 
masyarakat prasejahtera di Desa Pejaten diharapkan nantinya lebih lanjut dapat dipakai sebagai bekal untuk bekerja ataupun membuka usaha mandiri.

Dari pernyataan di atas dapat disimpulkan bahwa tidak hanya melakukan pendampingan pemberdayaan kepada masyarakat saja, melainkan harus disertai dengan pembekalan kreativitas dan inovasi sebagai media untuk menciptakan peluang kerja dengan berwirausaha. Pembekalan kreativitas dan invovasi yang akan diberikan dalam kegiatan pengabdian ini akan ditentukan kemudian sesuai dengan potensi yang dimiliki oleh masyarakat sasaran pada tahap evaluasi awal dengan metode Focus Group Discussion (FGD).

Tujuan dari kegiatan pengabdian pada masyarakat ini adalah untuk: (1) Membentuk kelompok yang termasuk ke dalam masyarakat prasejahtera di Desa Pajaten Kecamatan Sidamulih dengan memberikan pelatihan kreativitas dan inovasi produk makanan khas lokal sebagai media peluang kerja dan berwirausaha, dan (2) Melakukan pendampingan usaha dalam sektor produk unggulan desa.

\section{BAHAN DAN METODE}

Khalayak sasaran atau mitra dalam kegiatan ini adalah kelompok masyarakat yang tergolong ke dalam masyarakat prasejahtera di Desa Pajaten Kecamatan Sidamulih Kabupaten Pangandaran. Mitra tersebut dipilih berdasarkan keinginan yang sama untuk berwirausaha dan memiliki motivasi untuk dapat meningkatkan perekonomian keluarga.

Langkah-langkah yang ditempuh dalam kegiatan pengabdian ini adalah sebagai berikut:

1. Evaluasi awal

Pada tahap ini dilakukan metode Focus Group Discussion (FGD) untuk mengetahui potensi yang dimiliki masyarakat sasaran dalam membuat sebuah produk bernilai jual sebagai media usaha, sehingga dapat ditentukan produk apa yang akan dijadikan media usaha. FGD melibatkan masyarakat sasaran, pemerintah desa dan pihak terkait lainnya.

2. Meningkatkan keterampilan mitra dengan metode demonstrasi dan pelatihan

a. Demonstrasi yang dilakukan untuk memberikan contoh kepada peserta mengenai produk yang akan dijadikan media usaha termasuk menjelaskan produk inovasi yang akan diberikan beserta manfaat atas hasil produk inovasi tersebut.

b. Pelatihan melalui praktik langsung tentang semua tahapan pembuatan produk awal dan produk yang akan diinovasi.

3. Pendampingan usaha

Pemberdayaan masyarakat perlu digalakan untuk meningkatkan ekonomi keluarga. Pembentukan kelompok masyarakat yang mandiri secara ekonomi dengan dibekali 
keterampilan dan keahlian serta inovasi-inovasi tambahan mengenai produk-produk makanan khas daerah lokal diharapkan bisa meningkatkan taraf dan kesejahteraan hidup masyarakat. Disinilah peran motivator luar yang berfungsi melakukan persiapan sosial menjadi penting.

Tahap ini dilakukan dengan metode pendampingan dalam menjalankan usahanya. Masyarakat diberikan strategi maupun cara-cara pengelolaan produk tersebut agar bernilai jual tinggi dan tentunya bisa mencapai tujuan utama yaitu meningkatkan taraf dan kualitas hidup masyarakat prasejahtera.

4. Evaluasi akhir

Tahap ini adalah melakukan evaluasi untuk mengetahui keberlanjutan usaha yang sudah dilakukan masyarakat. Kesulitan-kesulitan maupun masalah-masalah yang ditemui oleh kelompok msyarakat prasejahtera diberikan solusinya agar pelatihan usaha dengan inovasi baru tersebut tetap bisa berjalan lancar dan bisa bernilai tinggi.

5. Pemantuan khusus untuk keberlanjutan

Tahap ini dilakukan untuk mengetahui tingkat motivasi mitra untuk terus berwirausaha. Mitra diharapkan tetap memiliki daya juang yang tinggi dalam mengembangkan usaha kreativitas dan inovasi terhadap produk yang akan dibuat tentu dengan tidak menghilangkan ciri khas produk lokal yang dimiliki.

\section{HASIL DAN PEMBAHASAN}

\section{Evaluasi Awal}

Evaluasi awal dilakukan pada hari Sabtu tanggal 2 Februari 2019 pada pukul 10.00 WIB sampai dengan pukul 12.00 WIB di Aula Kantor Desa Pejaten Kecamatan Sidamulih Kabupaten Pangandaran. Pada tahap ini dilakukan metode Focus Group Discussion (FGD) untuk mengetahui pengetahuan mitra tentang pembuatan keripik pisang rumput laut serta kemampuan mitra dalam mengelola usaha kecil. Selain itu, dalam FGD ini tim mencari tahu permasalahan-permasalahan yang menjadi hambatan yang dihadapi kelompok mitra. Peserta FGD dihadiri oleh kepala desa, para aparatur desa, kelompok mitra dan tim palaksana pengabdian.

Dari hasil diskusi dalam forum Focus Group Discussion (FGD) diperoleh beberapa informasi sebagai berikut: (1) Pengetahuan mitra mengenai pembuatan keripik pisang rumput laut masih rendah, (2) Pengetahuan mitra dalam mengelola usaha kecil masih rendah, (3) Tidak adanya tenaga ahli di Desa Pejaten untuk melakukan pendampingan dan pembimbingan 
terhadap kelompok mitra, dan (4) Masyarakat penghasil keripik pisang tidak dijadikan produk yang inovatif dan bernilai jual tinggi, hanya sebatas keripik pisang biasa.

\section{Pelatihan Pembuatan Keripik Pisang Rumput Laut}

Kegiatan pelatihan dilakukan pada hari Sabtu tanggal 16 Februari 2019 dari mulai pukul 09.00 WIB sampai dengan pukul 12.00 WIB bertempat di Aula Kantor Desa Pejaten Kecamatan Sidamulih Kabupaten Pangandaran. Pelatihan ini dilakukan dengan tujuan untuk memberikan pengetahuan serta meningkatkan keterampilan mitra dalam pembuatan keripik pisang rumput laut. Kegiatan pelatihan dilakukan dengan metode demonstrasi. Metode ini dipilih untuk menyampaikan tahapan-tahapan serta cara-cara pembuatan keripik pisang rumput laut yang penting untuk dimengerti oleh mitra.

Kondisi awal peserta mengenai cara-cara pembuatan keripik pisang rumput laut masih rendah. Peserta pada dasarnya hanya mengetahui produk keripik pisang dengan rasa yang asin dan manis saja. Dalam kesempatan tersebut tim pelaksana pengabdian dibantu dengan 3 orang mahasiswa memberikan pelatihan pembuatan keripik pisang dengan bumbu gurih rumput laut.

Setelah diberikan pelatihan pembuatan keripik pisang rumput laut, peserta telah mengalami perubahan dalam pembuatan produk tersebut. Para peserta dapat berinovasi dalam mengkreasikan produk yang berbahan dasar buah pisang, salah satunya adalah keripik pisang dengan bumbu rumput laut. Sehingga produk yang dihasilkan dapat menjadi produk andalan dan khas di Kabupaten Pangandaran.

Materi pelatihan yang diberikan adalah seputar pengenalan dan pembuatan keripik pisang dengan bumbu rumput laut. Dari contoh tersebut para peserta dapat mengkreasikannya dengan bumbu-bumbu yang lain, seperti bumbu matcha, keju dan lainnya, karena cara pembuatannya tidak terlalu berbeda, hanya berbeda dari bumbu saja. Pada pelaksanaan pelatihan ini tim pelaksana tidak mengalami kesulitan yang berarti, pengalaman dan naluri peserta yang merupakan kaum perempuan dalam membuat suatu produk makanan sangat membantu kami dalam proses kegiatan ini.

\section{Pelatihan Manajemen Usaha Kecil}

Pelatihan manajemen usaha kecil dilakukan pada hari yang sama dengan pelatihan pembuatan keripik rumput laut, yaitu pada hari sabtu tanggal 16 Februari 2019 pada pukul 13.00 WIB sampai dengan pukul 15.00 WIB di Aula Kantor Desa Pejaten Kecamatan Sidamulih Kabupaten Pangandaran. Kegiatan pelatihan ini menggunakan metode ceramah 
dan demonstrasi, dimana materi-materi yang diberikan kepada kedua mitra diseusaikan dengan kebutuhan peserta dan pengetahuan peserta untuk memahami konsep penting mengenai pengelolaan usaha kecil dalam rangka meningkatkan perekonomian keluarganya, sehingga materi yang diberikan dapat menjembatani peserta untuk dapat mengelola usahanya dalam memasarkan produk keripik pisang rumput laut.

Materi pengelolaan usaha kecil yang diberikan kepada peserta adalah sebagai berikut: (1) Motivasi berwirausaha, (2) Pengelolaan manajemen usaha kecil, (3) Pengelolaan permodalan usaha kecil, (4) Manajemen sumber daya manusia (MSDM), dan (5) Pengelolaan produksi usaha kecil.

Sesi terkahir dalam pelatihan manajemen usaha kecil para peserta diberikan waktu untuk bertanya terkait dengan materi yang diberikan. Secara umum dari beberapa peserta bertanya mengenai keingintahuan mereka mengenai pemasaran produk yang nantinya akan mereka pasarkan. Pemasaran merupakan kegiatan yang sangat diutamakan, karena menyangkut kuantitas dari penjualan produk mereka nantinya. Dengan adanya pelatihan ini terlihat ada perkembangan dari motivasi serta pemahaman mereka tentang pengelolaan usaha kecil.

\section{Pendampingan Usaha}

Pada tahap awal melakukan kegiatan usahanya, para peserta melakukan kegiatannya berdasarkan pesanan. Pada tahap ini kami membantu mempromosikan produk keripik pisang rumput laut yang mereka buat. Kegiatan pendampingan usaha ini bertujuan untuk memberikan pendampingan bagaimana mengelola usaha kecil dari awal pendirian usaha peserta. Dalam pendampingan usaha ini kami memberikan pemahaman mengenai hal-hal berikut ini: (1) Bagaimana mengelola permodalan usaha kecil, (2) Bagaimana mengelola keuangan usaha kecil, (3) Bagaimana pemasaran usaha kecil, dan (4) Bagaimana melakukan pengemasan produk sederhana untuk usaha kecil.

Dengan pendampingan ini diharapkan usaha yang di rintis oleh para peserta dapat maju dan berkembang, sehingga dapat dijadikan media untuk memperbaiki perekonomian mereka. Kegiatan pendampingan ini dilakukan pada hari Sabtu tanggal 23 Februari 2019.

\section{Evaluasi Akhir}

Evaluasi akhir dalam kegiatan ini dilakukan pada bulan Maret dengan melakukan kunjungan ke tempat usaha peserta yaitu pada hari Sabtu tanggal 29 Maret 2019. Kunjungan tersebut ditujukan untuk mengetahui tingkat pemahaman peserta dalam memahami materi- 
materi yang telah diberikan selama kegiatan berlangsung serta untuk mengetahui keterampilan peserta dalam membuat produk keripik pisang rumput laut dan menjalankan usahanya.

Berdasarkan hasil evaluasi yang dilakukan, para peserta dalam kegiatan ini mengalami perkembangan yang positif mengenai pemahaman terhadap materi-materi yang diberikan, sehingga mereka mulai melaksanakan usahanya sesuai arahan kami.

Kendala yang dihadapi dalam kegiatan ini adalah, kurangnya komitemen dari pihakpihak terkait untuk mengembangkan program kelompok usaha ini. Tidak adanya tenaga pendamping dari Kecamatan yang berasal dari Tenaga Kesejahteraan Sosial Kecamatan (TKSK), dimana hal tersebut merupakan suatu kendala untuk mengembangkan kelompok usaha dikemudian hari. Adanya tenaga pendamping dari TKSK merupakan salah satu syarat agar kelompok usaha yang telah dibentuk dan dibangun dapat memperoleh bantuan permodalan dari Kementerian Sosial melalui Bantuan Langsung Pemberdayaan Sosial (BLPS).

Berdasarkan hasil evaluasi yang telah dilakukan oleh tim pelaksana kegiatan, maka target dan realisasi hasil kegiatan dapat dilihat pada Tabel 1.

Tabel 1. Target dan Realisasi Hasil Kegiatan

\begin{tabular}{|c|c|c|c|}
\hline \multirow{2}{*}{ Kegiatan } & \multicolumn{2}{|c|}{ Indikator Kinerja } & \multirow{2}{*}{ Keterangan } \\
\hline & $\begin{array}{c}\text { Target } \\
\end{array}$ & Realisasi & \\
\hline $\begin{array}{l}\text { Evaluasi awal untuk } \\
\text { mengetahui potensi } \\
\text { yang dimiliki mitra } \\
\text { serta kendala-kendala } \\
\text { yang dihadapi mitar } \\
\text { dalam usaha }\end{array}$ & $\begin{array}{l}\text { Diketahuinya informasi } \\
\text { mengenai potensi } \\
\text { masyarakat serta kendala } \\
\text { yang dihadapi oleh mitra } \\
\text { dalam menjalankan } \\
\text { usahanya }(90 \%)\end{array}$ & $\begin{array}{l}\text { Dihasilkannya strategi } \\
\text { atau upaya-upaya dalam } \\
\text { menghadapi permasalahan } \\
\text { mitra dalam menjalankan } \\
\text { usahanya }(100 \%)\end{array}$ & \\
\hline $\begin{array}{l}\text { Pelatihan Pembuatan } \\
\text { Keripik Pisang } \\
\text { Rumput Laut }\end{array}$ & $\begin{array}{l}\text { Tingkat pemahaman dan } \\
\text { keterampilan mitra dalam } \\
\text { pembuatan keripik pisang } \\
\text { rumput laut }(80 \%)\end{array}$ & $\begin{array}{l}\text { Tingkat pemahaman dan } \\
\text { keterampilan mitra dalam } \\
\text { pembuatan keripik pisang } \\
\text { rumput laut }(100 \%)\end{array}$ & $\begin{array}{l}\text { Dihasilkannya produk } \\
\text { inovatif dan bernilai } \\
\text { jual tinggi }\end{array}$ \\
\hline $\begin{array}{l}\text { Pelatihan Manajemen } \\
\text { Usaha Kecil }\end{array}$ & $\begin{array}{l}\text { Tingkat pemahaman dan } \\
\text { keterampilan mitra } \\
\text { mengenai manajemen } \\
\text { usaha kecil }(80 \%)\end{array}$ & $\begin{array}{l}\text { Tingkat pemahaman dan } \\
\text { keterampilan mitra } \\
\text { mengenai manajemen } \\
\text { usaha kecil }(85 \%) \\
\end{array}$ & $\begin{array}{l}\text { Modul Manajemen } \\
\text { Usaha Kecil }\end{array}$ \\
\hline $\begin{array}{l}\text { Pendampingan } \\
\text { Usaha } \\
\text { Evaluasi akhir untuk } \\
\text { mengetahui } \\
\text { keberlanjutan KUBE }\end{array}$ & $\begin{array}{l}\text { Keterampilan mitra dalam } \\
\text { menjalankan usaha }(80 \%) \\
\text { Kemajuan kelompok } \\
\text { usaha }(70 \%)\end{array}$ & $\begin{array}{l}\text { Keterampilan mitra dalam } \\
\text { menjalankan usaha }(85 \%) \\
\text { Kemajuan kelompok } \\
\text { usaha }(75 \%)\end{array}$ & $\begin{array}{l}\text { Jasa Pendampingan } \\
\text { Usaha }\end{array}$ \\
\hline
\end{tabular}


Pemberdayaan Masyarakat Prasejahtera Melalui Inovasi Keripik Pisang Rumput Laut di Desa Pajaten Kecamatan Sidamulih

Regi Refian Garis, R. Rindu Garvera, Purnama Sari

\section{Pemantauan Khusus Untuk Keberlanjutan}

Kegiatan ini dilakukan untuk memantau perkembangan kegiatan peserta setelah selesainya kegiatan ini. Kegiatan pemantauan ini adalah untuk mengetahui motivasi peserta untuk terus berwirausaha. Hasil yang diperoleh adalah menurunnya motivasi sebagian peserta, sebanyak $80 \%$ peserta masih mempunyai keinginan yang besar untuk terus beriwirausaha, sedangkan sisanya sebanyak $20 \%$ peserta mulai mengalami penurunan motivasi untuk terus berwirausaha pasca selesainya kegiatan ini.

Kondisi tersebut disebabkan karena sebagian peserta memiliki motivasi hanya pada saat kegiatan berlangsung, selebihnya mereka berfikir setelah selesai kegiatan tidak ada tindaklanjut untuk kedepan. Sebagian peserta masih belum dapat berfikir mandiri, sehingga mereka terkesan harus terus mendapatkan pendampingan. Keberlanjutan kelompok usaha ini selayaknya harus terus mendapatkan perhatian khusus dari pihak-pihak terkait, terutama dari pihak Pemerintahan untuk terus membantu mereka dalam menjalankan usahanya, sehingga kelompok usaha ini dapat diperkuat dari segi permodalan yang berasal dari BLPS Kementerian Sosial Republik Indonesia.

Kegiatan Pengabdian Kepada Masayarkat (PKM) ini memiliki tujuan umum adalah untuk melakukan pembinaan kelompok-kelompok masyarakat sebagai media peningkatan taraf dan kualitas hidup mereka. Langkah yang sangat penting dalam proses pelibatan masyarakat itu adalah pembentukan Kelompok Usaha Bersama (KUBE). Melalui kelompok akan dibina solidaritas, kerjasama, musyawarah, rasa aman dan percaya kepada diri sendiri. Hal-hal tersebut dapat pula merujuk kepada ajaran agama. Salah satu cara yang efektif untuk membentuk kelompok adalah melalui pendekatan agama atau kepentingan yang sama secara primordial.

Langkah utama dalam kegiatan ini adalah memberikan penyuluhan kepada Kelompok Usaha Bersama (KUBE) kepada ibu-ibu rumah tangga yang termasuk kedalam kelompok keluarga prasejahtera. Produk yang dijadikan media usaha oleh kelompok tersebut adalah keripik pisang rumput laut. Alasan pembuatan produk keripik pisang rumput laut, dikarenakan di desa tersebut tidak sulit untuk mndapatkan bahan baku pisang dan rumput laut, sehingga hasil kebun pisang dan rumput laut tersebut dapat dimanfaatkan oleh masyarakat lainnya untuk dijadikan produk inovatif dan bernilai jual tinggi, yaitu keripik pisang rumput laut.

Selama kegiatan berlangsung peserta mendapatkan materi-materi yang diperlukan untuk menunjang kegiatan usaha mereka secara berkelanjutan. Materi yang diberikan seputar pemahaman dan keterampilan pembuatan keripik pisang rumput laut, pelatihan manajemen 
usaha kecil, serta melakukan pendampingan usaha. Dalam memberikan metri khususnya pelatihan membuat produk keripik pisang rumput laut, tim pelaksana tidak mengalami kesulitan, keran para peserta beranggotakan ibu-ibu rumah tangga yang sudah memiliki dasar dalam masak-memasak.

Selain itu masyarakat menyadari kegiatan produktif melalui kewirausahaan dapat meningkatkan kesejahteraan masyarakat desa yang masih menjunjung tinggi kearifan dan budaya lokal. Ekonomi kerakyatan dan padat karya yang masih dipertahankan dalam budaya masyarakat desa menjadikan perekonomian masyarakat desa berjalan dengan baik. Selain itu masyarakat sangat tertarik dengan adanya implementasi pemanfaatan teknologi informasi untuk kegiatan ekonomi masyarakat desa dan hal tersebut menjadi hal baru dalam upaya meningkatkan pemasaran produk unggulan desa tersebut.

Adanya inovasi keripik rasa rumput lain menjadi langkah awal kerjasama antara petani penghasil pisang dengan nelayan penghasil rumput laut di Pangandaran. Dengan adanya keripik rasa rumput laut menjadi produk unggulan desa Pajaten, menjadikan masyarakat bergairah dalam berwirausaha. Mereka menyimpan harapan baru dengan inovasi tersebut berhubungan dengan peningkatan kesejahteraan masyarakat setempat.

Hasil kegiatan menunjukan arah positif, dimana para peserta mamahami materi-materi yang diberikan. Hasil evaluasi awal tim pelaksana kegiatan ini mengetahui informasi mengenai potensi peserta untuk menjadi wirausahawan, serta dapat menemukan solusi dalam upaya-upaya mengadapi hambatan dalam menjalankan usaha mitra. Namun kendala yang dihadapi adalah tidak adanya tenaga pendamping dari Kecamatan yang berasal dari Tenaga Kesejahteraan Sosial Kecamatan (TKSK) merupakan suatu kendala untuk mengembangkan kelompok usaha tersebut dikemudian hari. Adanya tenaga pendamping dari TKSK merupakan salah satu syarat agar kelompok usaha yang telah dibentuk dan dibangun dapat memperoleh bantuan permodalan dari Kementerian Sosial melalui Bantuan Langsung Pemberdayaan Sosial (BLPS).

Tahap pemantuan khusus untuk keberlanjutan untuk mengetahui motivasi peserta agar dapat terus berwirausaha mengalami penurunan bagi sebagian peserta. Dimana sebanyak $80 \%$ peserta masih memiliki motivasi kuat untuk terus berwirausaha, sedangkan sisanya sebanyak $20 \%$ peserta tingkat motivasinya menurun. Hal tersebut disebabkan karena mereka masih berfikir bahwa kegiatan mereka kedepan harus terus mendapatkan pendampingan dari tim kegiatan, terlebih perhatian dari pemerintahan setempat tidak maksimal. Program KUBE ini selayaknya harus terus mendapatkan perhatian khusus dari pihak-pihak terkait, terutama dari pihak Pemerintahan untuk terus membantu mereka dalam menjalankan usahanya, sehingga 
program KUBE ini dapat diperkuat dari segi permodalan yang berasal dari BLPS Kementerian Sosial Republik Indonesia.

\section{KESIMPULAN DAN SARAN}

\section{Kesimpulan}

1. Terciptanya produk yang inovatif dan bernilai jual tinggi, yaitu produk keripik pisang rumput laut oleh Kelompok Usaha di Desa Pejaten Kecamatan Sidamulih Kabupaten Pangandaran.

2. Pelatihan manajemen usaha kecil dengan memberikan pemahaman mengenai bagaimana mengelola dan mengembangkan usaha kecil.

3. Melakukan pendampingan usaha kepada mitra, agar mitra paham dalam implementasi menjalankan usaha kecil kelompok.

4. Hasil evaluasi akhir menunjukan sebanyak $80 \%$ peserta masih memiliki motivasi untuk terus berwirausaha, sedangkan sisanya sebanyak $20 \%$ terjadi penurunan motivasi.

\section{Saran}

1. Para Peserta Kegiatan

a. Para peserta sebaiknya melakukan studi banding dengan beberapa kelompok yang telah berhasil dari segi usahanya dan dari segi pengelolaan keuangan usahanya, sehingga hal tersebut dapat dijadikan dasar dalam pengembangan kelompok.

b. Para peserta sebaiknya banyak berkonsultasi dengan para akademisi ataupun kepada mahasiswa yang ada disekitarnya terkait dengan pengelolaan usaha kecil.

\section{LPPM Unigal}

a. LPPM Unigal menindaklanjuti program ini dengan melibatkan dosen ahli, karena mitra masih memerlukan pendampingan untuk dapat menjankan usaha kecilnya.

b. LPPM Unigal hendaknya bekerjasama dengan pihak pemerintah (kecamatan atau Dinas Sosial) terkait dengan keberadaan kelompok usaha bersama, karena banyaknya persyaratan bantuan permodalan yang diberikan oleh Kementerian Soaial RI melalui BLPS.

\section{Pemerintahan}

a. Pihak kecamatan hendaknya melakukan pendampingan kepada KUBE yang berada di daerahnya, karena salah satu syarat permodalan melalui BLPS adalah pendampingan usaha yang dilakukan oleh Kecamatan. 
b. Dinas Sosial Kabupaten Pangandaran hendaknya memberikan perhatian penuh terhadap keberadaan KUBE di Kabupaten Pangandaran, sehingga kelompok tersebut dapat tumbuh dan berkembang sehingga dapat meningkatkan pertumbuhan ekonomi kedaerahan

\section{DAFTAR PUSTAKA}

Badan Pusat Statistik Jakarta Pusat. 2016. Statistik Indonesia Tahun 2016. Jakarta Pusat: Badan Pusat Statistik.

Ditejn Sumber Daya Sosial \& Pengentasan Kemiskinan. 2014. Pembentukan Kelompom Usaha Bersama Dalam Rangka Pengentasan Kemiskinan. Jakarta.

Fatah. 2013. Pengaruh Inovasi Produk dan Orientasi Pasar terhadap Keunggulan Bersaing (Survey pada UKM Batik Deden Tasikmalaya). Jurnal Fakultas Ekonomi. Unikom Bandung.

Karsidi, R. 2012. Sosiologi Pendidikan. Surakarta: LPP UMS \& UNS Pers.

Kotler \& Keller. 2012. Manajemen Pemasaran. Edisi 12. Jakarta: Erlangga.

Listyaningsih, U., Sumini, S. \& Satiti, S. 2016. Unmet Need: Konsep Yang Masih Perlu Diperdebatkan. Populasi, 24(1): 72-90.

Marwanti. 2011. Upaya Meningkatkan Kemampuan Berbahasa Anak Melalui Permainan Kaleng Bersuara di Taman Kanak-kanak Islam Bakti VI Kelompok A Tahun Ajaran 2011/2012. Surakarta: Universitas Muhammadiyah Surakarta.

McDaniel, C \& Gates, R. 2013. Riset Pemasaran Kontemporer (Sumiyarto dan Rambat Lupiyoadi, Penerjamah). Jakarta: Salemba Empat.

Nasution, A. 2013. Peranan Kredit Usaha Rakyat (KUR) bagi Pengembangan UMKM di Kota Medan (studi kasus Bank BRI). Jurnal Ekkonomi dan Keuangan Vol. 1, No. 3.

Yuniarti, E. 2014. Pemberdayaan Usaha Ekonomi Produktif Bagi Masyarakat Prasejahtera Di Kelurahan Harapan Jaya Bandar Lampung. IbM Ristekdikti. Politeknik Negeri Lampung. 